\title{
Watching the sky from the ushnu: the sukanka-like summit temple in Pueblo Viejo-Pucara (Lurin Valley, Peru)
}

\author{
Krzysztof Makowski ${ }^{1}$ and Clive L. N. Ruggles ${ }^{2}$ \\ ${ }^{1}$ Pontificia Universidad Católica del Perú, Department of Humanities-Archaeology, \\ Av. Universitaria 1801, Lima 32, Peru \\ email: kmakows@pucp.edu.pe \\ ${ }^{2}$ School of Archaeology and Ancient History, University of Leicester, \\ Leicester LE1 7RH, United Kingdom \\ email: rug@le.ac.uk
}

\begin{abstract}
Seen from the 'ushnu' platform in the palatial complex of Pueblo Viejo-Pucará, near Pachacamac, built by the Huarochirí people, the visual axis extends southwards towards two circular structures of the summit temple. Of these structures rising up from a monumental platform, one contains a sacred rock to which gold, silver and Spondylus princeps. were offered and the other housed a huanca-idol. These structures, and the ushnu, marked points and directions that are relevant for the organization of sacred geography, but whose location does not correspond to orientations that are astronomically relevant for calendrical calculations, contrary to the initial hypothesis.
\end{abstract}

Keywords. Inca Period, horizon astronomy, ushnu, llama constellation, Late Horizon summit temple, Huarochirí

In the past century, two themes have dominated the study of archaeoastronomy in the Central Andes: (1) Inca calendrics, in the context of the reconstruction of the ceque system of Cuzco, and (2) the hypothetical functions of geoglyphs in the central and southern coast, in particular in the basin of the Ingenio and the Valle Grande de Nazca. Occasionally, some scholars searched for astronomical alignments in buildings and plazas, for example at Chan Chan and Chavín. The development of field archaeology, with longterm projects, in the last few years has contributed to the expansion of this scenario. As comprehensive research programs on pre-Hispanic public architecture develop, evidence accumulates that these spaces may have incorporated in their design visual axes integrating plazas and platforms with the surrounding landscape, including the sky. Such axes seem to point to established places in the visual horizon, such as peaks, rock outcrops, passes between two peaks (abras), apachetas, etc. In some cases, such as Chankillo studied by Ghezzi \& Ruggles (2007), a set of towers formed a horizon observation device organized to maintain luni-solar calendars. The towers can be seen from the complex of ceremonial architecture. In Kalasasaya, in Tiwanaku, recently studied by Benítez (2009), the external platform room included stelae as sighting points that permitted a precise calendrical calculation from the apparent movement of the sun, as observed from the platform in the Plaza.

At Khonko Wankane, on the other hand, directions marked by corridors and entrances to the plaza, monumentalized in the form of gates, did not necessarily serve an astronomical function for calendrical purposes. According to Janusek (2010), such axes were chosen to construct the ceremonial space in which visual pathways oriented the 
participants in the rituals visually towards the most venerated apu peak in the southern horizon, Sajama, as well as towards the heliacal rising points of two llama-shaped Andean constellations, Catachillay with Deneb and Yacana with $\alpha$ and $\beta$ Centauri, on the days near the September equinox. This day is related to the end of the dry season, and the beginning of a new agricultural cycle. One of the two llama constellations is very likely represented in the Bennett monolith (Makowski 2009: fig. 6), the most imposing of two anthropomorphic sculptures that define the east-west ceremonial axis in the semi-subterranean Kalasasaya-Templete complex.

The topic of this paper also results from large-scale excavations of public architecture. In 1999, KM began excavation and preservation work at Pueblo Viejo-Pucara, which - judging by the ethnohistorical evidence, burial rites, and its typical highland architecture - was a major settlement of the Caringa of Huarochirí (Makowski 2002). Pueblo Viejo would therefore be the abode of the lords of the Caringa, the major chieftain on the left bank of the valley. Pueblo Viejo-Pucara lies less than $15 \mathrm{~km}$ from the ceremonial centre of Pachacamac, in the lomas (400-600m above sea level) grazing zone which is still used nowadays by the highland herders of Santo Domingo de los Olleros on the labyrinthine system of lateral ravines that criss-cross the initial spurs of the Andes. It is worth noting that Pueblo Viejo-Pucara visually dominates the access to Pachacamac from the south and the east. It is one of the few pre-Hispanic settlements in the valley lacking Late Intermediate Period antecedents. All stratigraphic levels contain ceramics diagnostic for the Inca period. It has been proved conclusively that the settlement was built during the Late Horizon and was abandoned shortly after the first contact with the Spaniards.

Its location on a site fortified by nature that lies in the midst of the lomas, the recurring associations with weapons manufacture, and the evidence of camelid husbandry, all suggest that Pueblo Viejo-Pucara was a dwelling place of Inca allies, a military detachment that was perhaps also in charge of managing the herds of the Pachacamac temple. This Late Horizon urban centre (llacta) is about 12ha in size (not counting the area associated with the agricultural terraces and minor sites on the periphery - in all some 26ha).

The excavations cover an area of more than $11,000 \mathrm{~m}^{2}$ and revealed two palatial dwellings, a small temple and part of all (four) residential precincts (Fig. 1). Each of the residential agglomerations comprises several courtyard-units with three to five groups of houses whose entrances open onto a common open area of irregular shape that may be partially enclosed. The architecture of the common houses and the elite dwellings has the same modular design. A module comprises two rectangular rooms interconnected by a passage, and two two-storey storerooms usually arranged in a row between the rooms, like a short passageway along the centre. Areas with human burials have been found in most of the residential groups. Some of the storerooms were turned into mortuary chambers to receive a varying number of individuals. The bodies seated in a flexed position were probably buried dressed and with no wrappings, to judge by the position of the bone elements and the ornaments according to the Sierra tradition (Salomon 1995). The spatial organization of the settlement brings to mind a social organization that is common in the highlands: two halves, an upper and a lower one, each with two precincts (for the common ayllus?), as well as a palace-like house with outbuildings (the home of the fifth ruling ayllu?).

Five of the structures, including the two with an orthogonal layout, are clearly elite dwellings and comprise two to six modules with porch-terraces whose entrance opens onto a common internal patio, access from the outside being restricted (Makowski et al. 2008). They also are the only ones that have a large double kitchen associated with the patio, along with evidence of drinks and food having been prepared for a large number of guests. 


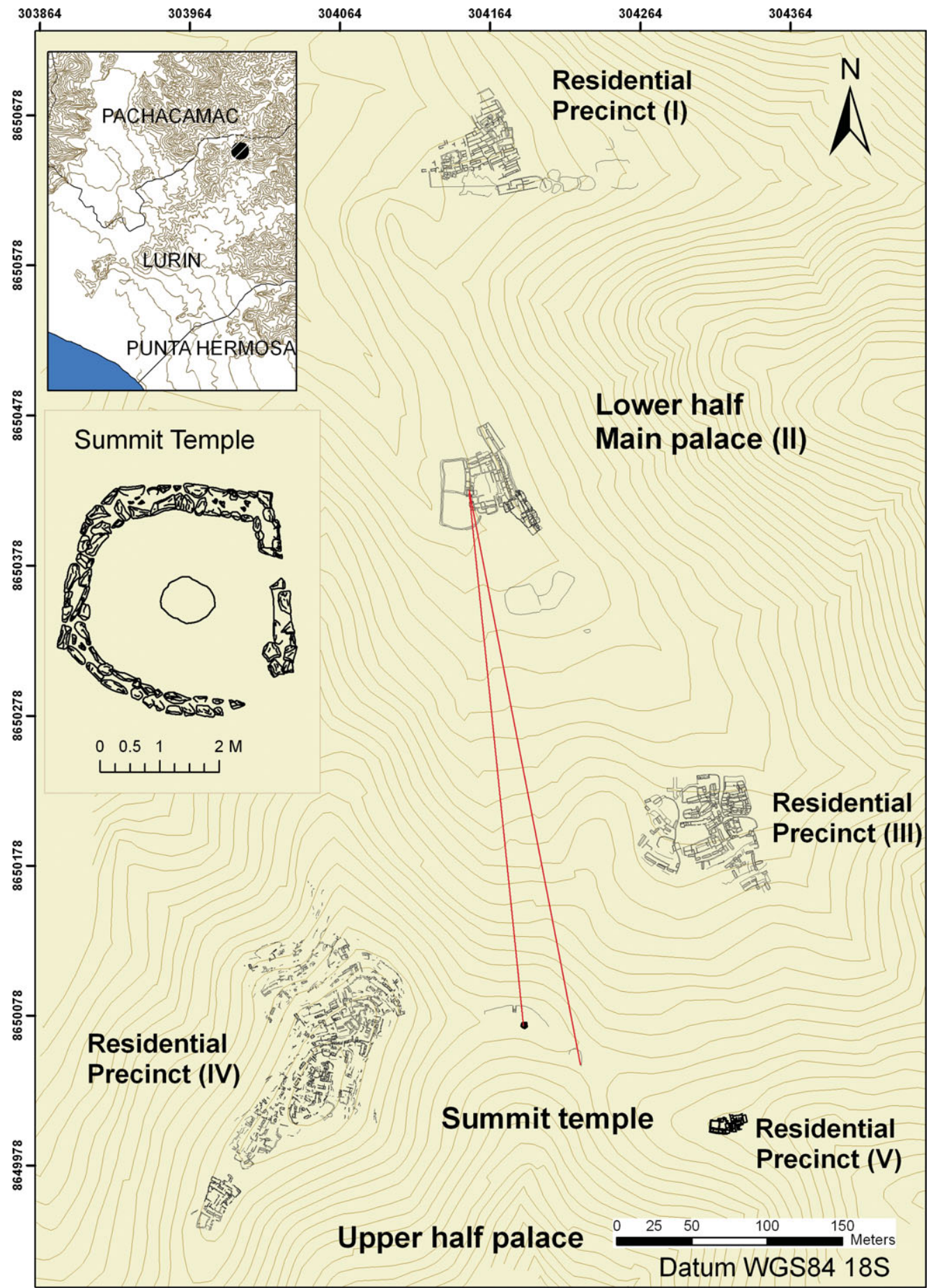

Figure 1. Map of Pueblo Viejo-Pucará, with four residential precincts, two in the upper and two in the lower half, and the main palace with an ushnu in the centre. The lines demarcate the angle of observation from the ushnu to the outer wall of each of the two sukanka-like circular structures in the summit temple. 


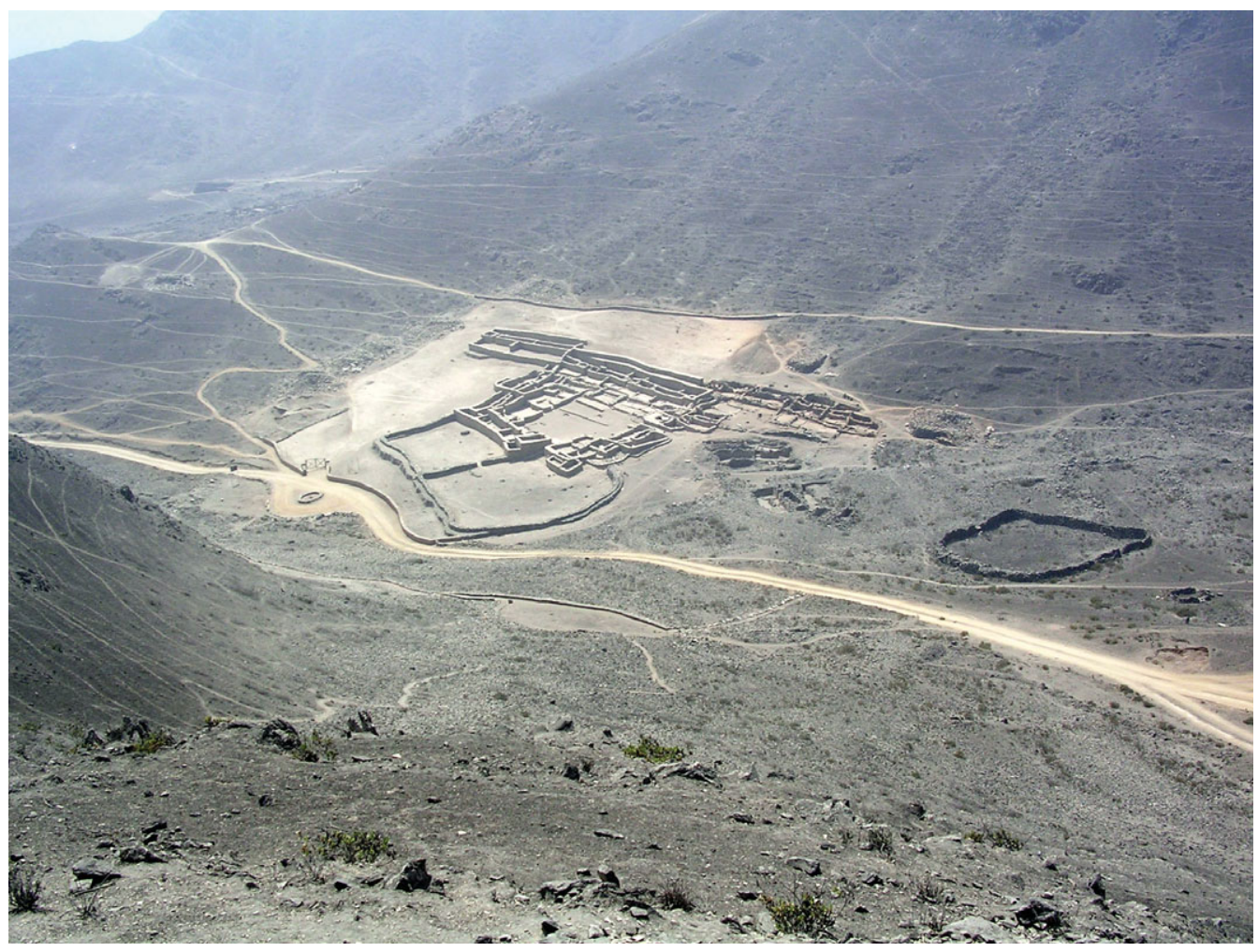

Figure 2. View of the palace after conservation.

Several outbuildings, including domestic enclosures and large corrals, are associated with the largest of these structures, which has a monumental aspect and three large patios (Fig. 2). Two of the patios are not connected with the domestic sectors, and probably had a ceremonial role, to judge by finds of Spondylus sp. and the presence of a large rock at its centre. The palaces are not Inca in design or stone masonry but the principal palace includes two ceremonial courtyards with a typical Inca altar (ushnu) for periodic libations. From the ushnu platform the visual axis extends toward the south, demarcated by the space between two circular structures of the temple. Of these structures rising up from a monumental platform, one contains a sacred rock to which gold, silver and Spondylus princeps. were offered and the other housed a huanca-idol. A second huanca-idol with an altar stands along the same axis, at the foot of the mountain in the middle of the yard.

The situation we describe will puzzle anyone familiar with the accounts of the ceque and huaca system of Cuzco by Polo de Ondegardo (1916 [1571]) and Cobo (Rowe 1979), as well the traditions of Huarochirí compiled by Avila (Salomon \& Urioste 1991). The material culture and customs of the people of Pueblo Viejo-Pucara are very similar to those recorded in the headwaters of the Lurin valley, in Huarochirí itself, where Avila recorded the traditions of the Checa. It is worth remembering that in chapter 29 of the Huarochirí manuscript, written around the 1600s, there is an extensive indigenous description of the night sky. This, together with other sources and the results of ethnographic studies in the community of Misminay near Cuzco, led Urton (1981) to propose a tentative reconstruction of the Andean organization of the night sky, whose principles differ substantially from European cosmology at the time of the conquest. 
Without pretending to exhaust the subject, we can call attention to the importance of the north-south axis and of the intercardinal directions projected onto the earth by the trajectory of Mayu, the Milky Way, and the Chacana constellation. The observation of dark constellations within the Milky Way, together with the tracking of the bright constellations, such as the Pleiades (Catachillay), played a substantial role in calendrical calculations (Zuidema 1982), as well as the prediction of rains, both for the people of Huarochirí in the 16th century and for those of Misminay in the 20th century. For both peoples, the volume of rains, and therefore the well-being of the community, depended on the behaviour of the Yacana, the mythical llama who drinks water from the river. The reappearance of the llama's head and eyes, $\alpha$ and $\beta$ Centauri, near the South Pole, indicated the beginning of the new agricultural cycle (Zuidema \& Urton 1976). Farmers predicted the intensity and duration of the rains from the intensity of the trajectory of the Yacana and other dark constellations near the southern cross such us Hanp'atu, 'toad'. It is interesting that the images of both zoomorphic constellations, from whose bodies grow crops, appear to have been embroidered in the famous Canepa tunic (today in Brooklyn museum) in approximately 0-300 AD (Makowski 2000: 304, fig. 52; Makowski 2005).

In this context, it catches our attention that the people of Pueblo Viejo-Pucara chose, when constructing the temple, to emphasize a portion of the visible horizon that is very close to astronomical south, as seen from the ushnu platform. Likewise, in the opposite direction along the axis, to the north, is the highest visible peak, whose summit contains offerings of shell. On the slopes of this mountain are found facilities to condense the fog and thus to obtain water for irrigation and a reservoir, most likely built by the people of Pueblo Viejo-Pucara. The ushnu itself warrants this name, despite not being part of an architectural complex in the Cuzco style, for several reasons. It is an elevated platform with an intentional fill of permeating gravel, which dominates two ceremonial plazas in whose surface were found Spondylus princeps and other fragmented molluscs. At its base has been found a sculptured vessel engraved with an image of corn cobs (Makowski et al. 2008). The platform is accessed by staircases from the ceremonial plazas and a ramp from the central patio of the palace, where evidence has been found of banquets with abundant consumption of corn beer and meat from deer and camelids.

On the other hand, several of the main elements that organized the sacred geography of the Cuzco ceque system (Zuidema 1964; Rowe 1979) are found in association with Pueblo Viejo-Pucara: the ushnu, the rock intentionally framed by stone masonry (cf. the 'Intihuatana de Pisaq'-Van de Guchte 1990: fig. 8), the huanca monoliths, and even, albeit hypothetically, the tower-like circular elevated structures, similar to sukankas (Williams León 2001). Zuidema has proposed in several articles that the observing point for the horizon in imperial Cuzco was located in the plazas adjacent to the canchapalaces of the Incas, in particular Hurin Haucaypata, where Cobo places the 'ushnu' huaca (Zuidema 1980, 1981 1982, 2008). Recently Pino Matos (2011) has demonstrated that astronomical observations to plan the layout of the Inca administrative centre of Huánuco Pampa were carried out from the ushnu.

Unlike the settlement, the summit temple of Pueblo Viejo-Pucara shows signs of a systematic and intentional destruction, performed, in all likelihood, by extirpators of idolatries. Only the retaining wall of the platform, with its monumental staircase of eight steps, remains intact. The circular defensive walls were dismantled down to their foundations. Their average width, and a comparison with the best preserved structures, suggests they may originally have reached a height of $3 \mathrm{~m}$. In that case, both of the circular structures would have been visible easily from the ushnu. The huanca monolith at the centre of the western structure, EA-65 (Fig. 3), was ripped out leaving a deep indentation. The second circular structure (EA-67) surrounds an intentionally worked rock outcrop. 


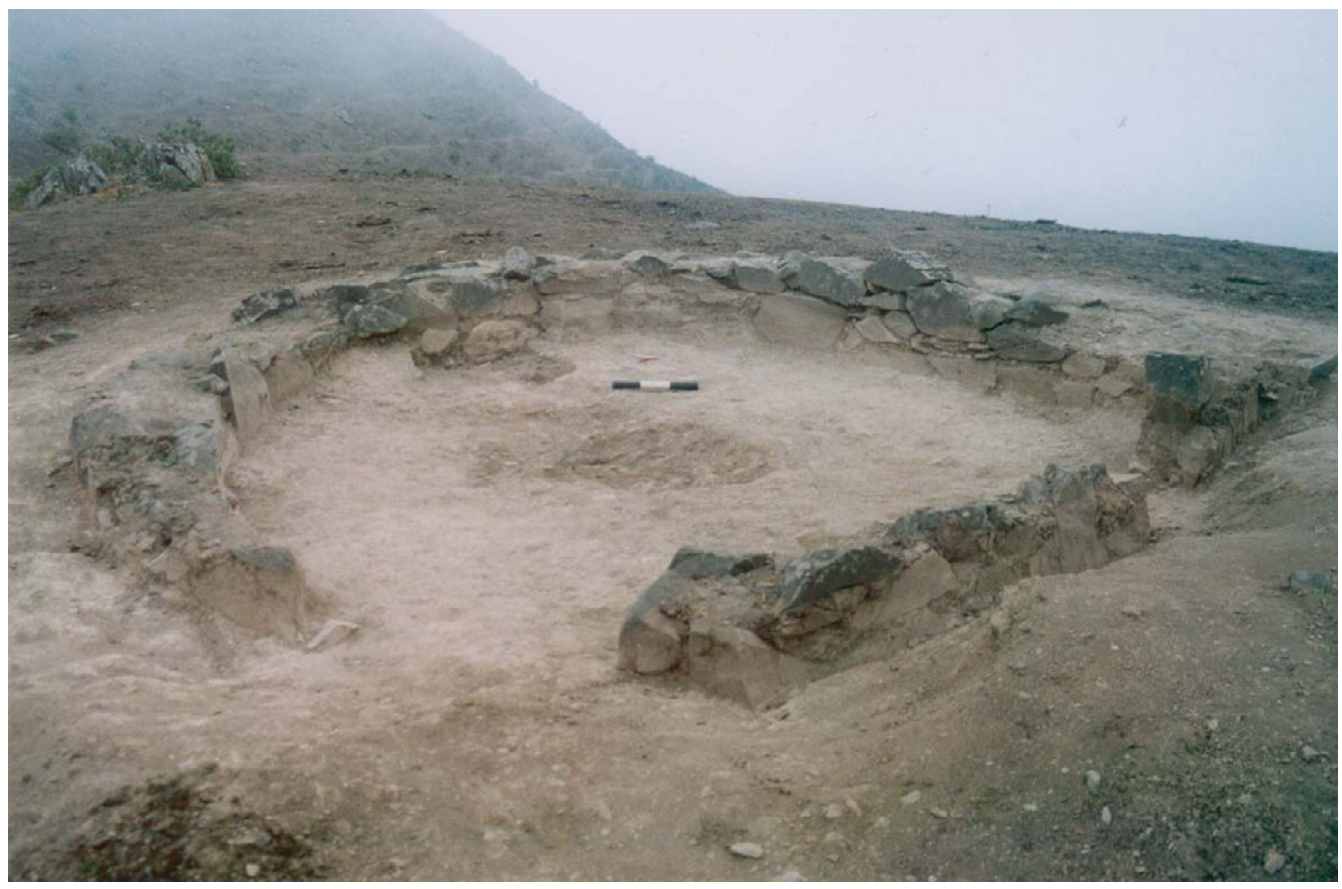

Figure 3. The summit temple's western structure (EA-65).

The offerings found in the crevices of the sacred rock and around it, consisting of gold beads and sheets, silver, and fragments of Spondylus princeps and sara-conopa, are similar to those received by the highest ranking sacred places (huacas) in Cuzco (Rowe 1979). Both structures have two ample points of access. Their width varies from $0.56 \mathrm{~m}$ to $0.85 \mathrm{~m}$. In the western structure, one entrance is oriented eastwards (az 105 ${ }^{\circ}$, the other to the SW (az 225 $)$. In the second structure, the entrances are oriented westwards $\left(\right.$ az $\left.255^{\circ}\right)$ and northwards $\left(\right.$ az $340^{\circ}$ ). The internal space of both structures is so small that one could not walk easily around either the huanca or the rock outcrop. The illumination from pre-established directions stands out as the only reason for the location of the double entrances. Tracking the progress of light and shadows projected through a narrow entrance over the surface of niches or small rooms was among the methods used to define ceremonial time in Inca architecture (Ziółkowski \& Sadowski 1992: 46-64, fig. 10).

The only huanca preserved in situ in Pueblo Viejo-Pucara is found in the middle of the livestock corrals south of the palace. The monolith is attached to a small stone platform, a possible shrine. Owing to its location, it is possible this is huanca marcayoc. The cult of the huancas - a Quechua word that means 'very large rock', according to Bertonio (1984 [1612]), or 'hard shaped stone' (Anonymous 1951 [1586]) — is also documented in ethnohistorical sources concerning the highlands of Lima. As attested by Duviols (1973, 1979) the huancas are always paired, and mark the centre of each half that makes up the ceremonial space of a community in the Central Andean highlands in the 16th and 17th centuries. One of the huancas, linked to the founding ancestor and protector of the urban nucleus (Huanca-marcayoc) was erected in the springs, canals, entrances or any other creation of the founder (Arriaga 1999 [1621]:128). Huanca marcayoc's counterpart is huanca chacrayoc (Arriaga 1999 [1621]). As its name suggests, it was located in the middle of cultivated fields, or in the boundary between these and the pastures. In the Andean highlands, the people (in Quechua, marca) are generally found near sources of 
water, in the valley bottoms or on the edge of the terraces that look over the entrenched valley. Conversely, the cultivated fields rise up the slopes almost to the limit of the pastures. So, a natural opposition arises between the centre of the productive half above and the centre of the populated half below. Within a classificatory scheme that recurs in Andean cultural reality, one of these centres is related to a male ancestor, the other to a female ancestor. In imperial Cuzco, the main male ancestor dominates the landscape from the summit of one of the mountains: e.g. Huanacuari, who merges with huanca marcayoc of Cuzco (the third of the Ayar brothers) and Zañu (the non-Inca ancestor) (Urbano 1981).

From the evidence presented above, we proposed two alternative scenarios to be tested by an archaeoastronomical study:

- Both circular structures in the summit temple served a purpose that was similar to the sukankas in imperial Cuzco, i.e. they marked the horizon points used to determine dates relevant for the ceremonial calendar.

- These structures, huanca marcayoc, and the ushnu marked points and directions that are relevant for the organization of sacred geography, but whose location does not correspond to orientations that are astronomically relevant for calendrical calculations.

A Total Station survey was duly carried out in October and November 2010 from the centre of the ushnu. Table 1 shows the azimuths, altitudes and declinations (at current ground level) of surveyed points in the Summit Temple. The azimuths confirm that if a monolith stood at the centre of EA65 it would have been just east of due south as viewed from the ushnu-by a little over 5 degrees.

An interesting feature about the horizon altitude in the southerly direction as viewed from the ushnu is that its altitude is around $12^{\circ}$. Since the latitude of the site is around $-12^{\circ}$, the south celestial pole will be more or less at horizon level in the due south direction. A little bit to the east, where the structures are, stars would be seen to rise almost vertically and then curve round the pole in a tight circular arc. (While the declination figures in the table refer to ground level at the structures, which seem to have been behind the horizon, the values will be little different at the altitude at which the stars would actually have appeared, since as just stated they would be rising almost vertically.) Nonetheless, there are no particularly bright stars or eye-catching asterisms that close to the pole. The stars of the Southern Cross and Pointers ( $\alpha$ and $\beta$ Centauri) would have risen much further to the left (declinations around $-60^{\circ}$ to $-55^{\circ}$, so rising at azimuths of about $145^{\circ}$ to $150^{\circ}$ ) and even the two Magellanic clouds, which are known to have

Table 1. Azimuths, altitudes and declinations (at current ground level) of points in the Summit Temple surveyed from the centre of the ushnu.

\begin{tabular}{|c|c|c|c|}
\hline Point & $\begin{array}{l}\text { True } \\
\text { azimuth } \\
\left({ }^{\circ}\right)\end{array}$ & $\begin{array}{l}\text { Altitude } \\
\left({ }^{\circ}\right)\end{array}$ & $\begin{array}{l}\text { Declin- } \\
\text { ation } \\
\left({ }^{\circ}\right)\end{array}$ \\
\hline Circular structure EA65, W side outer & 175.6 & 14.6 & -85.1 \\
\hline Circular structure EA65, E side outer & 175.3 & 14.5 & -84.9 \\
\hline $\begin{array}{l}\text { Templo de la Cima, Circular structure EA65, impression of } \\
\text { central monolith, W side }\end{array}$ & 174.9 & 14.4 & -84.6 \\
\hline $\begin{array}{l}\text { Templo de la Cima, Circular structure EA65, impression of } \\
\text { central monolith, E side }\end{array}$ & 174.3 & 14.5 & -84.0 \\
\hline $\begin{array}{l}\text { Templo de la Cima, Circular structure EA } 67 \text {, corner point in } \\
\text { wall on NNW side of structure, outer }\end{array}$ & 170.1 & 13.1 & -80.4 \\
\hline Templo de la Cima, Circular structure EA67, NW side outer & 169.3 & 12.7 & -79.5 \\
\hline
\end{tabular}


been significant to many southern hemisphere peoples, have declinations around $-70^{\circ}$ and would have risen at an azimuth of about $160^{\circ}$.

Therefore, the first interpretive scenario must be discarded. The circular structures did not act as horizon markers to set the date of ceremonies through the observation of one of the circumpolar constellations. Nevertheless, everything suggests that the choice of location, one of several suitable rock outcrops, is not casual. Beginning in November, the dry season is definitely over and the thick fogs disappear, except in anomalous years. A portion of the starry sky appears in the broad pass between the two peaks in Lomas de Pucara mountain that is seen to the south of the palace containing the ushnu, both to the left and right of the structure containing the huanca. The longer that the eyes of the llama, Yacana, and the toad, Hanp'atu, appear in this pass, the more intense will be the heat and the Lurin riverbed will fill with more water.

The features of the summit temple suggest that the mitmaquna Caringa of Huarochirí, resettled by imperial order to guard the flocks of Pachacamac and defend the oracle, moved themselves along with their paqarina: they moved the huaca of their ancestors and situated it in a new landscape right where it belongs: south of the ushnu.

\section{References}

Anonymous 1951 [1586], Vocabulario y Phrasis en la Lengua General de los Indios del Perú, llamada Quechua, ed. G. Escobar, UNMSM, Lima.

Arriaga, P. J. de 1999 [1621], La Extirpación de la Idolatría en el Piru, Centro de Estudios Regionales Andinos 'Bartolomé de la Casas', Cuzco.

Benitez, L. 2009, Descendents of the sun: calendars, myths and the Tiwanaku state. In M. Young-Sánchez (ed.), Tiwanaku: Papers from the 2005 Mayer Center Symposium in the Denver Art Museum, Denver Art Museum, Denver, pp. 49-82.

Bertonio, L. 1984 [1612], Vocabulario de la Lengua Aymara, CERES, IFEA \& MUSEF, La Paz.

Duviols, P. 1973, Huari y Llacuaz. Agricultores y pastores. Un dualismo prehispánico de oposición y complementariedad. Revista del Museo Nacional 39, 153-191.

Duviols P. 1979, Un symbolisme de l'occupation, de la ménagement et de l'exploitation de l'espace. Le monolithe 'Huanca' et sa fonction dans les Andes préhispaniques. L'Homme 19(2), 7-31.

Ghezzi, I. \& Ruggles, C. L. N. 2007, Chankillo: a 2300-year-old solar observatory in coastal Peru. Science 315, 1239-1243.

Janusek, W. J. 2010, El surgimiento del urbanismo en Tiwanaku y del poder político en el altiplano andino. In K. Makowski (ed.), Señores de los Imperios del Sol, Banco de Crédito del Perú, Lima, pp. 39-55.

Makowski, K. 2000, Los seres sobrenaturales en la iconografía Paracas y Nasca. In K. Makowski (ed.), Los Dioses del Antiguo Perú I, Banco de Crédito, Lima, pp. 277-307.

Makowski, K. 2002, Arquitectura, estilo e identidad en el Horizonte Tardío: el sitio Pueblo Viejo-Pucara, valle de Lurín. Boletín de Arqueología PUCP 6, 137-170.

Makowski, K. 2005, La imagen de la sociedad y del mundo sobrenatural en el manto de Brooklyn. In V. Solanilla Demestre (ed.), Tejiendo Sueños en el Cono Sur, Textiles Andinos: Pasado, Presente y Futuro. Actas del Simposio ARQ-21, 51 Congreso Internacional de Americanistas, Santiago de Chile, 14-18 julio de 2003, Grup d'Estudis Precolombins, Universitat de Barcelona, Barcelona, pp. 102-123.

Makowski, K. 2009, Royal statues, staff gods and the religious ideology of the prehistoric state of Tiwanaku. In M. Young-Sánchez (ed.), Tiwanaku: Papers from the 2005 Mayer Center Symposium in the Denver Art Museum, Denver Art Museum, Denver, pp. 133-164.

Makowski, K., Córdova, M., Habetler, P., \& Lizárraga, M. 2008, La plaza y la fiesta: reflexiones acerca de la función de los patios en la arquitectura pública de los periodos tardíos. Boletín de Arqueología PUCP 9, 297-333.

Pino Matos, J. L. 2011, La organización espacial-calendárica y los observatorios astronómicos de Tambokancha-Zurite y Huánuco Pampa: dos asentamientos Inka como centro de Paisaje 
Sagrado en los Andes Centrales. Presentation at the 'Oxford IX' international symposium on archaeoastronomy, Lima Peru.

Polo de Ondegardo, J. 1916 [1571], Informaciones Acerca de la Religión y Gobierno de los Incas, Colección Urteaga-Romero, tomos III y IV, Lima.

Rowe, J. H. 1979, An account of the shrines of ancient Cuzco. Ñawpa Pacha 17, 1-80.

Salomon, F. 1995, 'The beautiful grandparents': Andean ancestor shrines and mortuary ritual as seen through colonial records. In T. Dillehay (ed.), Tombs for the Living: Andean Mortuary Practices, Dumbarton Oaks Research Library and Collection, Washington DC, pp. 315-353.

Salomon, F. \& Urioste, J. 1991, The Huarochiri Manuscript: a Testament of Ancient and Colonial Andean Religion (often attributed to Francisco de Avila, University of Texas Press, Austin.

Urbano, E. 1981, Wiracocha y Ayar: Héroes y Funciones en las Sociedades Andinas, Centro de los Estudios Rurales Andinos Bartolomé de las Casas, Cusco.

Urton, G. 1981, At the Crossroads of the Earth and the Sky: an Andean Cosmology, University of Texas Press, Austin.

Van de Guchte, M. 1990, 'Carving the World': Inca Monumental Sculpture and Landscape, University Microfilms, Ann Arbor.

Williams León, C. 2001, Sukankas, quipus y ceques: el tiempo y la sacralización del espacio en el Cusco. Revista del Museo Nacional 49, 123-162.

Ziółkowski, M. \& Sadowski, R. 1992, La Arqueostronomía en la Investigación de las Culturas Andinas, Instituto Otavaleño de Antropología, Quito.

Zuidema, R. T. 1964, The Ceque System of Cuzco: the Social Organization of the Capital of the Inca, E. J. Brill, Leiden.

Zuidema, R. T. \& Urton G. 1976, La constellación de la llama en los Andes peruanos. Allpanchis Phuturinqa 9, 59-119.

Zuidema, R. T. 1980, El Ushnu. Revista de la Universidad Complutense de Madrid 28 (117), $317-362$.

Zuidema, R. T. 1981, Inca observations of the solar and lunar passages through zenith and antizenith at Cuzco. In R. A. Williamson (ed.). Archaeoastronomy in the Americas, Ballena Press, Palo Alto CA, pp. 319-342.

Zuidema, R. T. 1982, Catachillay: the role of the Pleiades and of the Southern Cross and Alpha and Beta Centauri in the Calendar of the Incas. In A. F. Aveni \& G. Urton (eds), Ethnoastronomy and Archaeoastronomy in the American Tropics, New York Academy of Sciences, New York, pp. 203-229.

Zuidema, R. T. 2008, The astronomical significance of ritual movements in the calendar of Cuzco. In: J. E. Staller (ed.), Pre-Columbian Landscapes of Creation and Origin, Springer, New York, pp. 249-267. 